\title{
Straw Based Biorefinery
}

\author{
AK Ray* \\ Indian Institute of Technology Roorkee, India
}

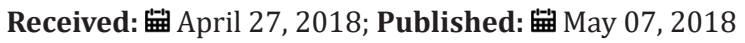

*Corresponding author: AK Ray, Professor \& Emeritus Fellow (Retired), Indian Institute of Technology Roorkee, India,

Email: amiyakumarray@gmail.com

\begin{abstract}
In India energy security and exploring the production of valuable chemicals, which are otherwise mostly imported have become imperative necessity The advantage of abundant availability of paddy and its straws, specifically the rice straw in India are taken as an example to establish a perfect Bio-refinery . In these paper possibilities of production of chemicals and energy by Chemical, Biochemical and Thermo chemical platforms are explored. Possible alternatives on the problems of stubble burning in some stares of India are put forward. However, studies on the optimal design, and economic viability of each routes remain to be evaluated.
\end{abstract}

\section{Introduction}

Biorefineries similar to petroleum refineries is a facility developed, engineered and designed optimally where renewable energy (heat \& power) and multiples of chemical products and can be profitably manufactured from biomass with best known environmentally benign process technologies through biochemical and thermo chemical platforms. The energy production from bipomass is also Greenhouse neutral. Cellulosic biomass, because of its massive availability, can be a truly biorefinery representing a

feedstock for biofuels and valuable chemicals. Agricultural residues such as straws are ideal candidates for establishing a biorefinery in India. Presently major quantity of straws is used as domestic fuels in rural areas. Rice Straw is produced from Rice Paddy. The various products and by-products are shown in the schematic diagram (Figure 1). On an average, there is $20 \%$ husks, $10 \%$ bran, $3 \%$ polishings, $1-17 \%$ broken rice and $50-66 \%$ polished rice. Generally Rice Paddy by-products is on an average $30 \%$ weight of paddy3).

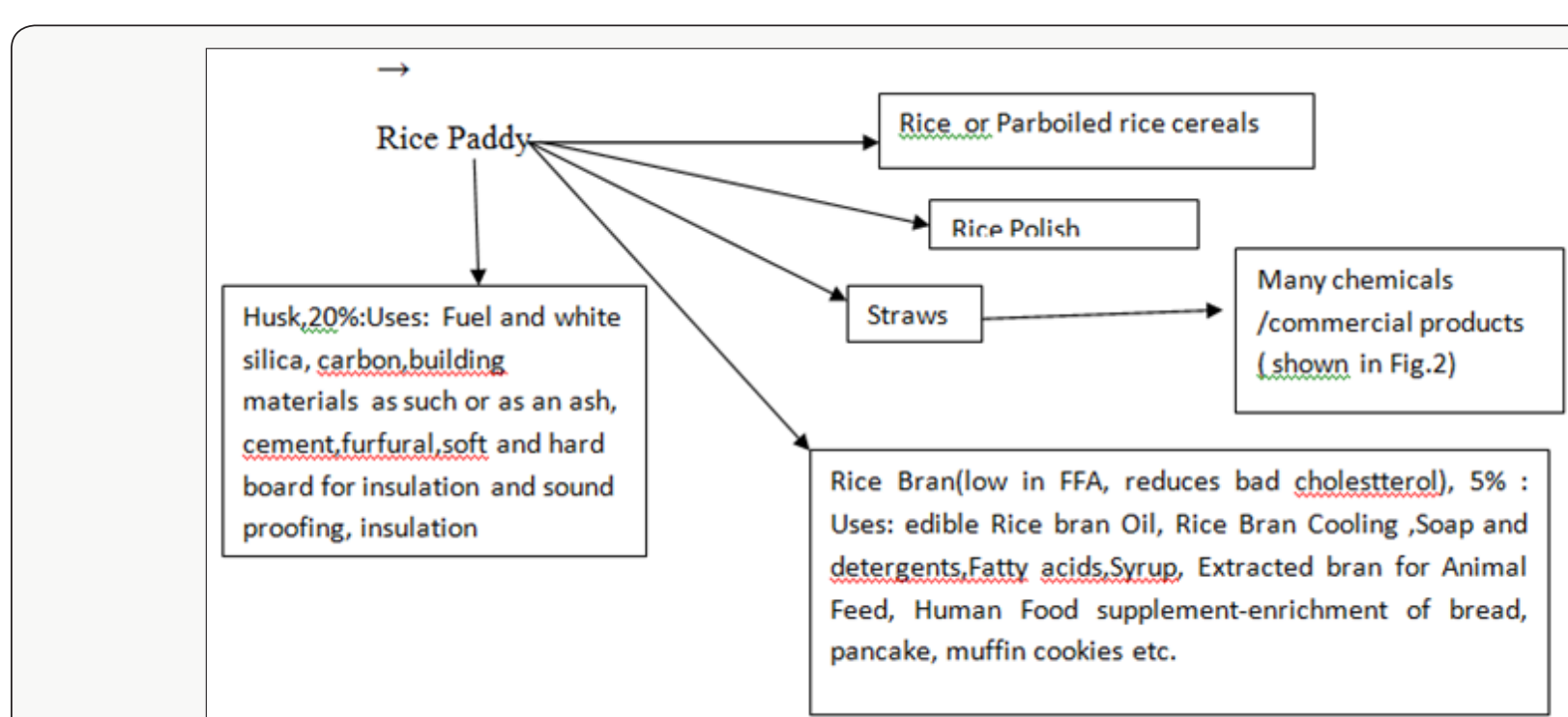

Figure 1: Products and Bye-products from Rice Paddy (2). 
The residual wastes (stubbles) are usually burnt in the field which leads to severe air pollution problems due to discharge of gaseous pollutants including $\mathrm{CO}$, Ozone , $\mathrm{N}_{2} \mathrm{O}, \mathrm{NO}_{\mathrm{x}^{\prime}} \mathrm{SO}_{2}, \mathrm{CH}_{4^{\prime}}$ particulate matters ,smokes and smogs, hydrocarbons. Open burning of crop stubble also results in the emissions of harmful chemicals like polychlorinated dibenzo-p-dioxins, polycyclic aromatic hydrocarbons (PAH's) and polychlorinated dibenzofurans (PCDFs) referred as as dioxins, besides loss of nutritional values of soil intermas of organic carbon, nitrogen, phosphorous and potassium in many states of India, especially Punjab, Haryana, Rajasthan and Uttar Pradesh. This is not that extent in other part of India. The main reasons are: larger length of the stubbles remains after harvesting in those states which cannot be economically covered under soil to enhance the fertility of the land and attempts to burn these long projected straws over the agricultural land. In the following paragraphs some alternatives to straw stubble burning are suggested [1].

Due to continuous depletion of non-renewable energy resources and high cost of chemicals due to import, at present there is a worldwide attention towards development of renewable resources of energy and chemicals for sustainable development for the welfare of mankind. For example: Economic production of bioethanol from lignocellusic biomass. Conversion of lignocellulosic plant materials to biochemicals is also regarded as one of the most promising alternatives to fossil fuels. Most abundantly available biomass in the countries like India and China are straws (rice, wheat, oats, rye, barleys, Zea Mays, corn stalks etc.), out of which rice straw occupies the first position and followed by wheat straw in terms of availability in Eastern, and North Eastern Indian states (West Bengal, Bihar, Assam, Orissa, Manipur etc.) whereas reverse is true for Northern India (U.P. Haryana, Punjab, Rajasthan etc.).

\section{Conventional but Economic Uses of Rice Straw and} Stubbles
a) Soil improver to increase the fertility
b) Manuring/Composting with cowdung and others etc.
c) Briquettes
d) mats
e) Mushroom cultivation(as growth substrate)
f) Vegetables Cultivation
g) Animal Bedding material
h) Poultry Litter \& Mulch
i) Feed for ruminants/Animal feed
j) Packaging goods for transporting goods \&machineries
k) Frost prevention in horticulture
l) Strawberries (preventing damage to the fruit)
m) Thatching
n) Rope making
o) Traditional building materials, fibre boards,Particle board, insulation material

\section{p) Energy (heat, power, fuels)}

q) An intergrated solid state fermentation approach for production of enzymes from agro-wastes including straws

Lignocellulosic biomass could thus be utilized for both production of biofuels as well as biochemical's due to its nature of renewability, low price, widespread availability and containing high content of pentose and hexose sugar polymers. These are detailed elsewhere [2-6]. Straw and Stubbles can be used for various Chemicals, valuable products and energy. The most notable products which can economically manufactured are: Pulp \& Paper, Particle Board, Pulp and Paper Board, Straw board, board of rice husk.

Energy technologies and thermal combustion consists of NonConventional uses of straws. Valuable chemicals include Cellulose, High Alpha cellulose, Plastics, Fuels and Energy,Bio-gas and in situ, Bio-oil, Nanocellulose and nano composites, Pentosans, Xylose, Xylitol, $\alpha$-Cellulose, Glucose , Fructose, Hydroxy methyl Furan, Ethanol and host of many other chemicals [7-10]. These are shown in Figure 2.

Refineries based on Cellulose, Ethanol, Sucrose, Glucose, Lignin have been proposed and given elsewhere various Unit Operations and Processes involved to produce a biorefinery are as under:
a) Pulping
b) Gasification
c) Pyrolysis
d) Destructive distillation
e) Plasma Treatment
f) Chemical Treatment
g) Electron Irradiation

\section{Chemical platform}
a) Activated carbon
b) Chemical transformation through Catalyst(Sn-beta zeolites)
c) Synthetic Fuel using Solar Furnace
d) Cellulose nano crystals and nanocomposites:
Cellulose nanocrystals have been largely applied as reinforcing fillers in the preparation of nano composites materials with improved mechanical and barrier properties. 


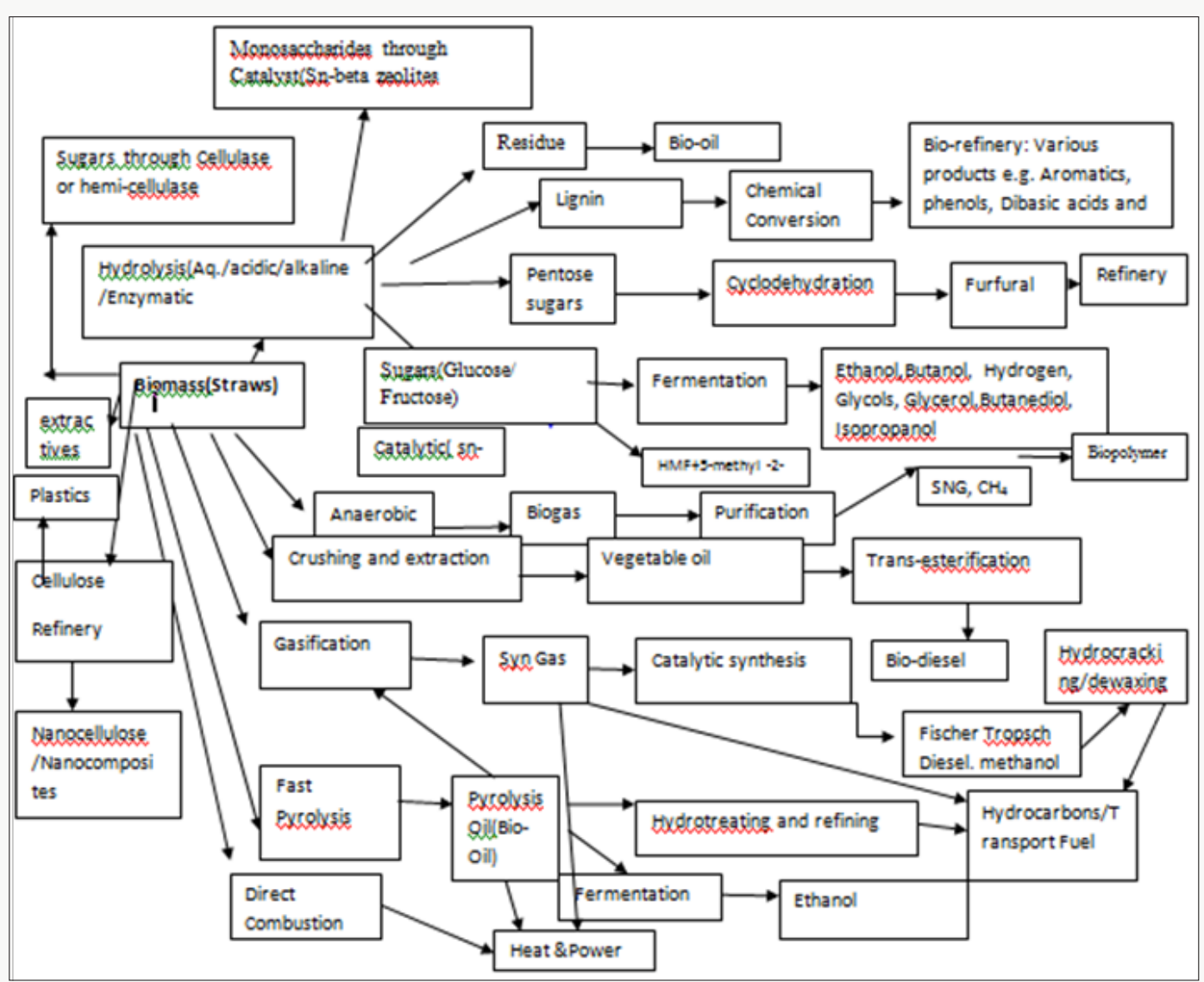

Figure 2: Different conversion routes from biomass to Energy/Power and value added chemicals (30).

\section{Bio-chemical platform}

Biorefinery based on Cellulose to Chemical Intermediates consisting of Products \& Chemicals is shown in Figure 4. This platform divide the product in five different categories as classified below:

a) Renewable fuels: Ethanol, Biodiesel,Butanol, Hydrogen

b) Chemicals: Acetone,Furfurol,Propanediol, Ketones etc.

c) Organic Acids:Acetic, Lactic, Succinic, Gluconic, Butyric etc.

d) Bio-Energy: Lignate, Methane, Bio-gas, Heat, Electricity

e) Food \& Feed: Single Cell Protein,Fat,Fiber, Sugar etc.

\section{Chemistry of Formation}

\section{Monosachharides}

D-Xylose,D-glucose, L-arabinose,Xylitol,fructose,D-mannose,Dgalactose

\section{Hemicellulose}

Furfural, through acid treatment, Biogas by anaerobic Digestion, concentrating to Animal Feed. Fructose /Fruit sugar $\rightarrow$ Hydroxymethyl furfural (HMF) $\rightarrow$ catalytic processes $\rightarrow$ Plastics, diesel fuel additives, or even diesel fuel [11,12].

\section{Chemical or Biochemical Platforms: Dilute acid hydroly- sis of lignocelluloses:}

Acids: Carboxylic acids such as formic acid, acetic acid, 3-hydroxy propionic acids, succinic acid, fumaric acids, Malic acids, Itaconic acids, Levulinic acid, Glucaric acids, glucuronic acid, Vanillic acids, Syringic acids, Ferulic acids, p-coumarlic acid. Amino acids like Aspartic acids, Glutamic acids, Aldehyde: Syringaldehyde

Polyphenols: glycerol, Arabitol, Xylitol, Sorbitol Lactones such as 3-hydroxy butyrolactone

Phenolics: p-hydroxy benzoic acids and vanillin However,aldopentose xylose $(20-40 \%$ of the total carbohydrates are normally found in agricultural residues.

Reaction Schemes $(4,9,21,29,30)$

Chemical reaction consists of series, parallel and combination of series-parallel reactions

Cellulose (Glucan) $\rightarrow$ Oligosaccharides $\rightarrow$ Glucose $\rightarrow \mathrm{HMF} \rightarrow$ Levulinic acid

Hemicellulose $\rightarrow$ Oligosachharides $\rightarrow$ Sugars( xylose,arabinose, glucose, mannose, galactose)

Pentoses (Xylose/ Arabinose) $\rightarrow$ Furfural $\rightarrow$ Furfural resinification and condensation products 
Hexoses(Glucose/ Fructose ) $\rightarrow \mathrm{HMF} \rightarrow$ Levulinic acid+Formic acid $\rightarrow$ Succinic acid

\section{Furfural and HMF}

Figure 3 Reaction Scheme and Kinetic models are developed (Pentosan( both xylan and arabinan) is hydrolyzed to both aldopentoses which are converted into two or more steps into furfural. Loss of furfural takes place due to side reactions which leads to condensation and to the formation of resins. Both levulinic acid and furfural can be produced from straw or any biomass \& levulinic acid can be converted to succinic acid and formic acid [13].

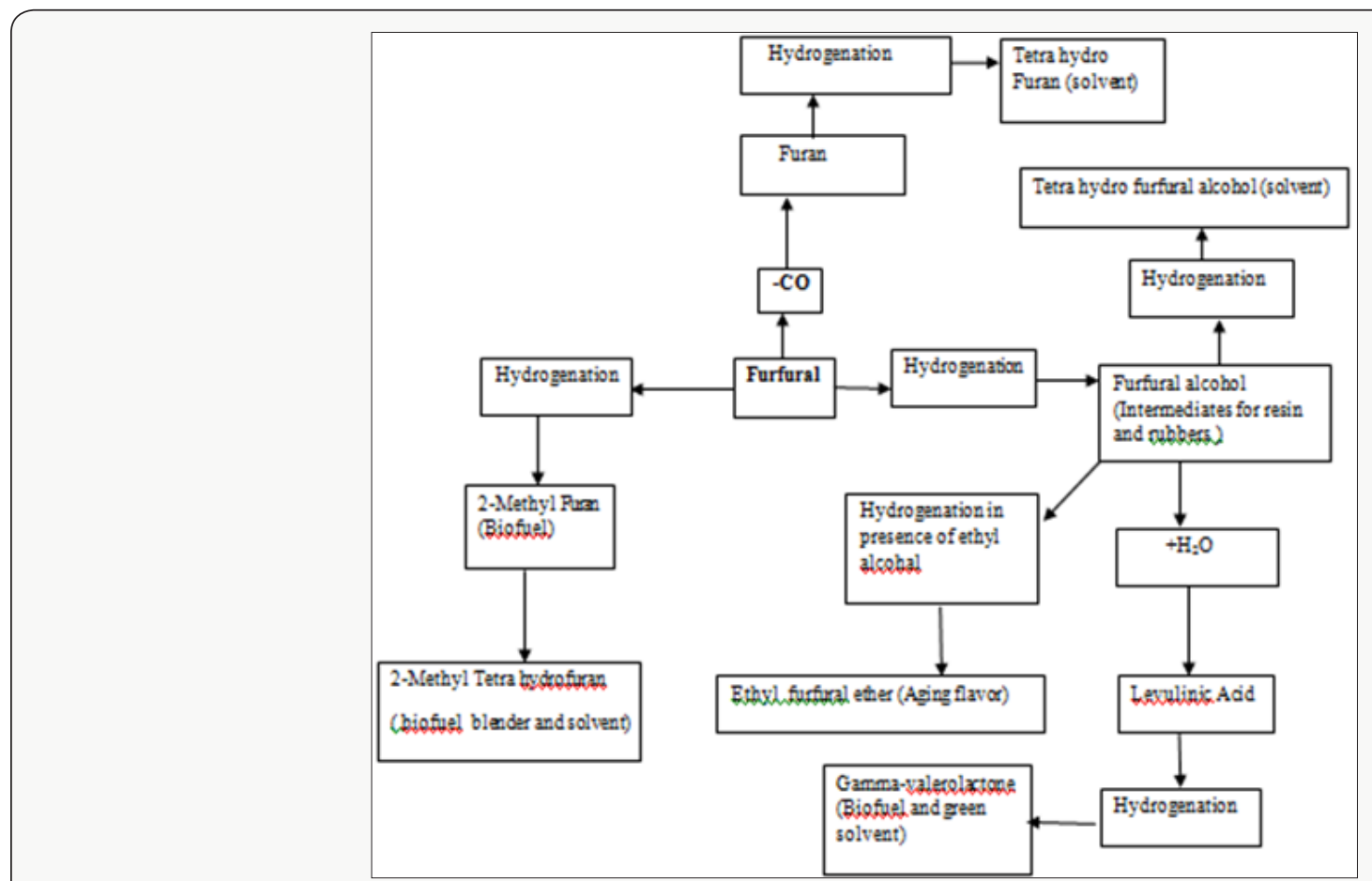

Figure 3: Furfural based Bio-refinery (30).

\section{Chemistry of formation}

Furfural: $\mathrm{C}_{5} \mathrm{H}_{8} \mathrm{O}_{4}+\mathrm{H}_{2} \mathrm{O} \rightarrow \mathrm{C}_{5} \mathrm{H}_{10} \mathrm{O}_{5} \rightarrow \mathrm{C}_{5} \mathrm{H}_{4} \mathrm{O}_{2}+3 \mathrm{H}_{2} \mathrm{O}$

Xylan Xylose Furfural: Hexosan $\rightarrow$ Hexose (Unit Cellulose) $\rightarrow$ 5-hydroxymethyl-2-furfural + 5-methyl -2-furfural

\section{Mechanism:}

Hydrolysis:

$$
\begin{gathered}
\text { xylan }+ \text { water } \stackrel{H+}{\longrightarrow} \text { Xylose } \\
\text { arbinan }+ \text { water } \stackrel{H+}{\longrightarrow} \text { arabinose }
\end{gathered}
$$

\section{Dehydration:}

$$
\begin{aligned}
& \text { xylose }-3(\text { water }) \stackrel{-H+}{\longrightarrow} \text { furfural } \\
& \text { arbinose }-3(\text { water }) \stackrel{-H+}{\longrightarrow} \text { furfural }
\end{aligned}
$$

Furan derivatives such as Furfural (2-furaldehyde), HMF (5-hydroxymethyl-2-furaldehyde), 2,5 furan dicarboxylic acids(33-35) are most important chemicals. HMF is produced industrially on a modest scale as a carbon-neutral feedstock for the production of fuels and other chemicals such as levulinic acid, gamma-valerolactone, or other byproducts. HMF itself has few applications and it is primarily produced in order to be converted into other more useful compounds [14-20]. Of these the most important is 2,5-furandicarboxylic acid, which has been proposed as a replacement for terephthalic acid in the production of polyesters. HMF can be converted to 2,5-dimethylfuran (DMF), a liquid that is a potential biofuel with a greater energy content than bioethanol. Hydrogenation gives 2,5-bis(hydroxymethyl) furan. Acid-catalysed hydrolysis converts HMF into gamma-valerolactone, with loss of formic acid. HMF is practically absent in fresh food, but it is naturally generated in sugar-containing food during heat-treatments like drying or cooking. Along with many other flavor- and color-related substances, HMF is formed in the Maillard reaction as well as during caramelization. In these foods it is also slowly generated during storage. Acid conditions favour generation of HMF. HMF is a well known component of baked goods. Upon toasting bread, the amount increases from 14.8 ( $5 \mathrm{~min}$.) to $2024.8 \mathrm{mg} / \mathrm{kg}$ (60 $\mathrm{min})$. It is a good wine storage time-temperature marker, especially in sweet wines such as Madeira and those sweetened with grape concentrate arrope [21-24].

\section{Fermentation Technology}

\section{Bio-Ethanol}

Sachharomyces cerevisiae, Zymomonous Mobilis, Clostidium thermocellum, Ruminococcus albus- a bacterium are generally 
used for conversion of cellulose to ethanol. Theoretically $1 \mathrm{~kg}$ of sucrose on inversion, gives $1.053 \mathrm{~kg}$ of invert sugar, glucose and fructose combined together. Further,one tone of invert sugar yields 644.8 litres of absolute alcohol(ethanol of $100 \%$ ) or 678.7 litres of rectified spirit.The net $\mathrm{CO} 2$ emission of burning a biofuel like ethanol is zero since the $\mathrm{CO} 2$ emitted on combustion is equal to that aabsorbed from the atmosphere by photosynthesis during growth of the plant(sugarcane) used to manufacture ethanol.

Inversion: $\mathrm{C}_{12} \mathrm{H}_{22} \mathrm{O}_{11}+\mathrm{H}_{2} \mathrm{O} \rightarrow \mathrm{C}_{6} \mathrm{H}_{12} \mathrm{O}_{6}+\mathrm{C}_{6} \mathrm{H}_{12} \mathrm{O}_{6}$

Sucrose + Water $\rightarrow$ Invertase $\rightarrow$ Glucose + Fructose (Invert Sugars)

Fermentation: $\mathrm{C}_{6} \mathrm{H}_{12} \mathrm{O}_{6} \rightarrow 2 \mathrm{C}_{2} \mathrm{H}_{5} \mathrm{OH}+2 \mathrm{CO}_{2}+27.8 \mathrm{kCals}$ Xymase

Oxidation: $\mathrm{C}_{2} \mathrm{H}_{6} \mathrm{O}+3 \mathrm{O}_{2} \rightarrow 2 \mathrm{CO}_{2}+3 \mathrm{H}_{2} \mathrm{O}+\Delta$

Combined equation: $\mathrm{C}_{6} \mathrm{H}_{12} \mathrm{O}_{6}+6 \mathrm{O}_{2} \rightarrow 6 \mathrm{CO}_{2}+6 \mathrm{H}_{2} \mathrm{O}+\Delta$
Photosynthesis: $6 \mathrm{CO}_{2}+6 \mathrm{H}_{2} \mathrm{O}+h v($ light $) \rightarrow \mathrm{C}_{6} \mathrm{H}_{12} \mathrm{O}_{6}+6 \mathrm{O}_{2}$

\section{Butanol}

Biobutanol is produced by microbial fermentation, similar to bioethanol, and can be made from cellulosic feedstocks such as straws. The most commonly used microorganisms are strains of Clostridium acetobutylicum and Clostridium beijerinckii, C. Saccharoperbutylacetonicum and C. saccharobutylicum. In addition to butanol, these organisms also produce acetone and ethanol, so the process is often referred to as the "ABE (acetone-butanolethanol) fermentation [25-30]. Production of lactic acid from straw derived cellulose,cellulase production with Tricoderma citriviridae on solid bed, use of acid hydrolysates for lactic acid production using various strains such as Lactobacillus delbrueckii or lactobacillus pentosus can be explored.A number of products can be produced from sucrose as shown in Figure 4.

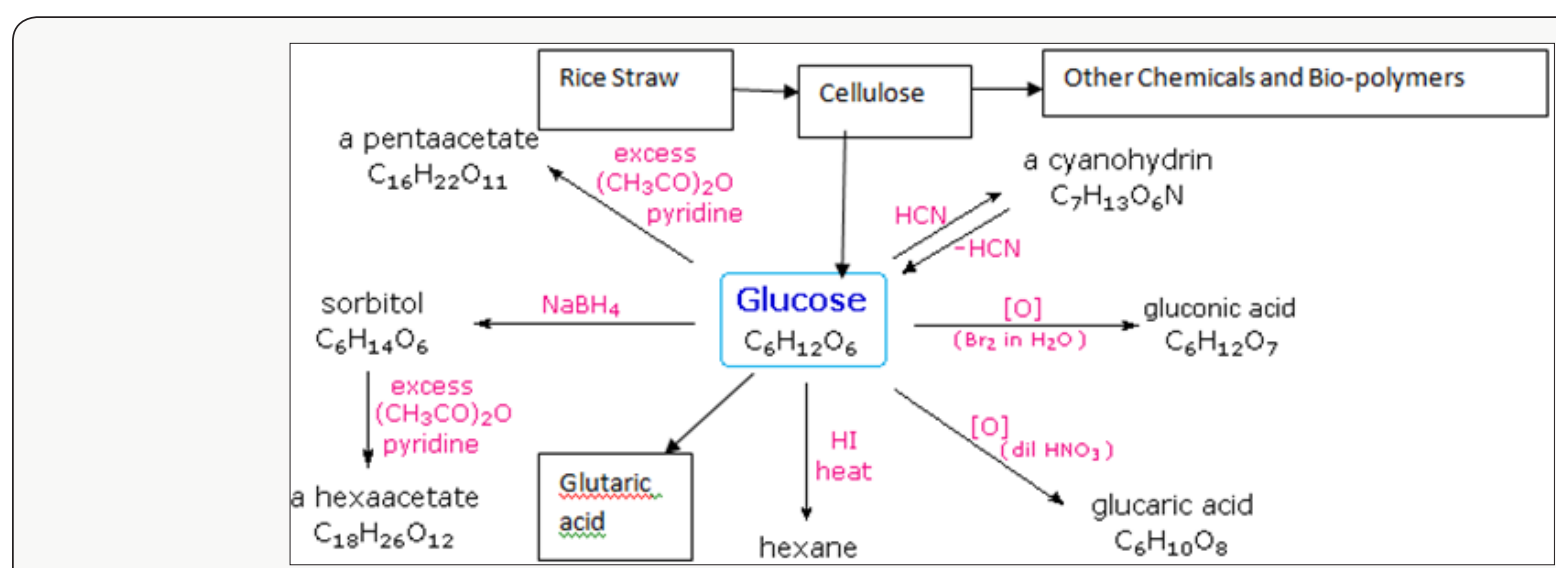

Figure 4: Glucose based biorefinery (Wikipadia).

\section{Anaerobic Digestion}

Biogas production (25,31-32), Anaerobic conversion of carbohydrate /cellulosics, especially of agricultural residues, has been considered for biogas ( methane) production which is typically, $\mathrm{CH}_{4}=50-65 \%, \quad \mathrm{CO}_{2}=35-50 \%, \quad \mathrm{H}_{2} \mathrm{O}=30-160 \mathrm{~g} / \mathrm{m}^{3}, \quad \mathrm{H}_{2} \mathrm{~S}=1.5-12.5 \mathrm{~g} /$ $\mathrm{m}^{3}$ inn presence of methane producing bacteria. Typically some of the methane forming microorganisms likes Methanaomonas, Methanococcous mazei n.sp. methannobacterium sohn genii n.sp. etc. are employed. The two best described pathways involve the use of acetic acid or inorganic carbon dioxide as terminal electron acceptors:

$$
\begin{aligned}
& \mathrm{CO}_{2}+4 \mathrm{H}_{2} \rightarrow \mathrm{CH}_{4}+2 \mathrm{H}_{2} \mathrm{O} \\
& \mathrm{CH}_{3} \mathrm{COOH} \rightarrow \mathrm{CH}_{4}+\mathrm{CO}_{2}
\end{aligned}
$$

During anaerobic respiration of carbohydrates, $\mathrm{H} 2$ and acetate are formed in a ratio of 2:1 or lower, so $\mathrm{H} 2$ contributes only ca. $33 \%$ to methanogenesis [31], with acetate contributing the greater proportion. In some circumstances, for instance in the rumen, where acetate is largely absorbed into the bloodstream of the host, the contribution of $\mathrm{H} 2$ to methanogenesis is greater.

Buswell and Symons universal equation:
$\mathrm{C}_{n} \mathrm{H}_{a} \mathrm{O}_{b}+(n-a / 4-b / 2) \mathrm{H}_{2} \mathrm{O} \rightarrow(n / 2-a / 8+b / 4) \mathrm{CO}_{2}+(n / 2+a / 8-b / 4) \mathrm{CH}_{4}$

\section{Thermo-chemical platform}

\section{Gasification Technology}

The basic principles of Gasification technology are as under:

\section{a. Steam Reforming of Straws:}

Superheated steam reacts endothermally (consumes heat) with the carbonaceous components of straws to produce hydrogen and carbon monoxide fuel gases (synthesis gas or syngas)

b. Steam Reforming reaction: $\mathrm{H}_{2} \mathrm{O}+\mathrm{C}+\mathrm{Heat} \rightarrow \mathrm{H}_{2}+\mathrm{CO}$

Water -gas shift reactions also occur simultaneously with the steam reforming reactions to yield additional hydrogen and carbon dioxide.

c. Water gas shift reaction: $\mathrm{H}_{2} \mathrm{O}+\mathrm{CO} \rightarrow \mathrm{H}_{2-}+\mathrm{CO}_{2}$

\section{Conclusion}

India being an agriculture based country with plenty of biomass renewable resources can produce potential bio-products and bio- 
energy at a cheaper rate compared to other renewable sources. Being carbon neutral these resources is eco friendly, yields much less green house gaseous emissions compared to fossil fuels [3237]. In this present paper various alternatives for straw utilization, specifically the plausible solutions of current problems of straw stubble burnings in a few Indian states are highlighted. However detailed optimum design of process and plant with economic feasibility need to work out.

\section{References}

1. Kumar P, Kumar S, Joshi L (2015) Socioeconomic and Environmental implications of Agricultural Residue Burning-A case study of Punjab, India.

2. Florbela Carvalheiro, Luis C.Duarte, Francisco M.Girio (2008) Hemicellulose biorefinerries: a review on biomass pretreatments. Journal of Scientific \& Industrial Research pp. 849-864.

3. AN Bose (1976) Rice Processing Industry: A Key Industry for Country's Survival-HL Roy Memorial Lecture. Indian Chemical Engineer an-arch 18(1).

4. Surendra Pratap Yadav, Uttam Kumar Ghosh, Amiya Kumar Ray (2016) A Fresh Look at the Kinetics of Pentosan Removal from Lignocellulosic Biomass. American Journal of Chemical Engineering 4(6): 161-169.

5. Bhardwaj NK, GoyalSanjeev K, Gupta Ajay, Upadhyaya JS, Ray AK (2005) Soda and Soda-anthraquinone pulping of ricestraw 58(3): 180-185.

6. Goyal SK, Ray AK, Bhardwaj NK, Gupta A (1998) Pulping studies of rice straw using Soda and soda anthraquinone process. Proc TAPPI pp. 227238.

7. Ray AK, Mathur Ashish, Verma KV (1991) An attempt to analyze rice straw based mechano-chemical pulp for processing. Pulping Conference pp. 223-233.

8. Hurter AM (1988) Utilization Of Annual Plants And Agricultural Residues For the Production of Pulp And paper. TAPPI Proceedings, Pulping Conference pp. 139-161.

9. Surendra P Yadav, AK Ray, UK Ghosh (2016) Optimization of Rice Straw Acid Hydrolysis Using Response Surface Methodology. American Journal of Environmental Engineering 6(6): 174-183

10. Anita S, Narsi RB (2012) Optimization of enzymatic hydrolysis of pretreated rice straw and ethanol production. J Bioenergy and Biofuels 93(4): 1785-93.

11. Esther GR, Oscar MP, Lorezo JE, Jose AR,Manuel V (2012) Acid hydrolysis of wheat straw: a kinetic study. J Biomass \& Bioenergy 36(1): 346-355.

12. Ines CR, Solange I Mussatto, R Rodrigues (2003) Dilute acid hydrolysis for optimization of xylose recovery from rice straw in semi-pilot reactor. J Industrial crops \& products 17(3): 171-176.

13. Karim K, Kheradmandinia S, Taherzadeh MJ (2006) Conversion of rice straw to sugars by dilute-acid hydrolysis. J Biomass \& Bioenergy 30(3): 247-253.

14. Seoung CB, Kwon YJ (2007) Optimization of the pretreatment of rice straw hemicellulosic hydrolysates for Microbial Production of Xylitol. J Biotechnology and Bioprocess Engineering 12(4): 404-409.

15. Ting-Hiang L, Chiung-Fang H, Gia Luen G, Wen Song H, Huang L (2012) Pilot scale ethanol production from rice-straw hydrolysates using xylose fermenting Pichia stipits. J Bioreource Technology pp. 314-319.

16. Mohan R, Prasad R, Yadav R, Ray AK, Rao NJ (1988) Pulping Studies of wheat Straw Using Soda and Soda- AQ Process. Proceeding of the international non wood Pulping and Paper making conference pp. 339348.
17. Goyal SK, Ray AK (1989) Economic comparison of Soda and soda anthrax quinone process of cereal straws. TAPPI Pulping Conference proceeding pp. 775-780.

18. Ray AK, Rao NJ, Kumar N, Arora AK, Mehrotra A (1990) Soda-Oxygen Delignification of rice straw. TAPPI Pulping Conference pp. 499-505.

19. AK Ray, Pradosh Sanyal (2011) Alternative Uses of Sugarcane Molasses and Jagerry for production of value added fatty acids, especially Oxalic acid. Sustainability and Biobased Materials 17002, Proceedings of 11 AIChE Annual Meeting, held between Oct.16-Oct.21, at Minneapolis, Minnesota, USA, pp. 238.

20. Amiya Kumar Ray, Pradosh Sanyal (2011) Biorefinery based on Indian Distillery- Innovation of Forest Products. 17000, Proceedings of 11 AIChE Annual Meeting, held between Oct.16-Oct.21, at Minneapolis, Minnesota, USA, Paper 228d, pp. 206.

21. AK Ray, Sanjay Tyagi, Narayan Chandra Mishra (2011) Biorefinery based on Indian Paper Industry Wastes. Biobased materials II: LigninBased Materials, 17004, Proceedings of 11 AIChE Annual Meeting, held between Oct.16-Oct.21, at Minneapolis, Minnesota, USA,Paper 499a, pp. 289.

22. AK Ray, KM Srinivas, Mukesh Kumar (2011) Utilization of Sugar Industry by-products, the bagasse pith for manufacture of Furfural. Biobased materials III: Value -added Coproducts, 17005, Proceedings of 11 AIChE Annual Meeting, held between Oct.16-Oct.21, at Minneapolis, Minnesota, USA, paper 566c, pp.308.

23. Amiya K Ray, Jacques J Garceau, Bahuslav V Kokta, Felix Carrasco (2011) Steam Explosion Pulping of Indian Non-Wood Fibres. Sustainable Forest Bioresources Engineering, T4B09, Proceedings of 11 AIChE Annual Meeting, held between Oct.16-Oct.21, at Minneapolis, Minnesota, USA, Paper192p, pp.194

24. AK Ray, Narayan C, Mishra (2012) Exploring Lignin Based Biorefinery in India. Proceedings of 12 AIChE Annual Meeting held at Pittsburgh, USA.

25. Amiya Kumar Ray, RB Nigam, SK Sharma, P Sanyal (2012) Sugar Cane Refinery -Production of Sugarcane Wax From Sulphitation Press Mud. Proceedings of 12 AIChE Annual Meeting held at Pittsburgh, USA.

26. Pooja Sharma, UK Ghosh, AK Ray (2013) Dynamic Modelling and Simulation of Anaerobic Digester For High Organic Strength Waste. AIChE 2013 Annual meeting held at SanFrascisco, USA.

27. AK Ray, Tushar Utgata, Pabitra Kumar (2013) Mohanty Removal and Recovery of Dye from Paper Machine Efffluents by Continuous Column Method.

28. AK Ray, Surendra Yadav, Pooja Sharma (2013) Economic Production Of BIO-Ethanol From Various Indigenous Sources In India-A Review.

29. AK Ray, Ravimohan, Rajnikant Prasad, Rajeev Yadav (2013) A fresh look at the $\mathrm{H}$ factor data for indian nonwood agri-residues.

30. Yadav Surendra Pratap (2017) Ph.D. thesis Mathematical Modeling of Furfural Production from Lignocellulosic Biomass. IITRoorkee, India.

31. Surendra Pratap Yadav, AK Ray, UK Ghosh, 663a Study of the Hydrolysis of Rice Straw Using Phosphoric Acid,Amberlite Catalyst and Process Optimization Using RSM Methodology.

32. Sharma P, Ghosh UK, Ray AK (2014) Kinetic study of anaerobic digestion of sewage sludge/high organic strength industrial waste, Proceeding, Environmental Division. Annual Meeting, American Institute of Chemical Engineers, USA.

33. Sharma P, Ghosh UK, Ray AK (2015) Kinetic modelling and simulation of anaerobic digester of industrial effluent and sludges, Environmental Division. Annual Meeting, American Institute of Chemical Engineers AICHE, USA

34. Kläusli Thomas (2014) AVA Biochem: commercialising renewable platform chemical 5-HMF. Green Processing and Synthesis 3(3). 
35. Huber George W, Iborra Sara, Corma Avelino (2006) Synthesis of Transportation Fuels from Biomass: Chemistry, Catalysts, and Engineering. Chem Rev 106(9): 4044-98.
36. Lewkowski J (2001) Synthesis, chemistry and applications of 5-hydroxymethyl-furfural and its derivatives. Arkivoc 1: 17-54.

37. www.wikipadia.
(C) (1) This work is licensed under Creative

To Submit Your Article Click Here:

Submit Article

DOI: $10.32474 /$ AOICS.2018.02.000149

\section{AOICS}

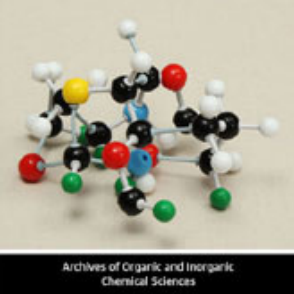

\section{Archives of Organic and Inorganic} Chemical Sciences

Assets of Publishing with us

- Global archiving of articles

- Immediate, unrestricted online access

- Rigorous Peer Review Process

- Authors Retain Copyrights

- Unique DOI for all articles 